\title{
Impact of Performance Appraisal on Employee's Performance Including the Moderating Role of Motivation: A Survey of Commercial Banks in Dera Ismail Khan, Khyber Pakhtunkhwa, Pakistan
}

\author{
Zafrullah Khan, Abdul Sattar Khan*, Irfanullah Khan \\ Department of Public Administration, Gomal University, Pakistan
}

Copyright $\subset 2017$ by authors, all rights reserved. Authors agree that this article remains permanently open access under the terms of the Creative Commons Attribution License 4.0 International License

\begin{abstract}
The study focuses on the association between performance evaluation and employees' performance and motivation as a moderator. The results demonstrate that there is critical association between performance evaluation and performance of employees of commercial banks of Dera Ismail Khan. A total of one hundred and fifty (150) employees of banks were studied in Dera Ismail khan, it was concluded that the motivation which is the moderating variable can change the performance of employees' and was considered as a deciding variable in employee performance. The results are given in a table where we can observe that although Model 2 with the interaction between performance appraisal and employees motivation accounted for more variance than just performance appraisal and employees' motivation level by themselves, $\mathrm{R}^{2}$ change $=.006$ however it is insignificant with $\mathrm{p}=.168$, indicating that there are no moderation effects of employees motivation on the relationship between performance appraisal and employees performance.
\end{abstract}

Keywords Performance Appraisal (PA), Employee Performance (EP), Moderating Role of Motivation (MRM)

\section{Introduction}

\subsection{Background of the Study}

The formal performance appraisal system in human resource management becomes a buzzword that dragged the attention of both experts and researchers. The formal performance management systems start as a practice for polishing the human capacities. These capacities might incorporate the observing of employees, the assessment of contracting and preparing techniques and the approval of human resource management practices Moreover, the framework of a performance appraisal system is perplexing because of the numerous measurements developed by the managers for evaluating consequences in different setup. Performance appraisal is also being seen as having direct influence on job satisfaction and motivation of workers (Ahmad. R, \& Ali. NZ, 2004). Thus it becomes a big challenge for the human resource professionals to provide better motivating techniques for good performance.

In contemporary era, verging on each organization whether it is public or private requires a framework to assess their employee's performance. The managerial information, ability, standards, commitment and appraisals might influence the employee's performance (Ikram, M, et. al; 2011). In nineteenth century Taylor's practiced a performance appraisal system predominantly and merit rating was developed through close system for legitimizing employee's wages and performance Actually, an employee performance appraisal system is used by the manager's to strengthen the human potentials hence to gain maximum benefit. Performance appraisal is that instrument which can be utilized to oversee employee's performance successfully. Research reveals that Performance appraisal framework creates the association between supplementary pay and remunerates competent work forces and enhance their inspiration and overall commitments. (Giangreco, et al., 2012).

The performance appraisal can be seen as the systematic description of individual job-relevant strength and weakness for the purpose of making a decision about the individual (Ahmad \& Bujang, 20I3) .It can therefore be construed that an evaluation framework can extremely depend on vital measures, neither suitable nor reasonable, especially to the representative, whose performance is being assessed (Jan, et.al, 2014).

The literature revealed that performance appraisals are a 
practice to measure how individual employees are acting and how they can enhance their performance in the organization (Mohammad, M et.al, 2012). Motivation or commitment is the technique which is commonly used for capacity building. Motivation is a determined power that leads and coordinated a man toward some particular goals (Iskandar, et al., 2013). Performance management guides and persuades employees to expand their endeavors for the benefit of the organization to meet its key destinations.

Performance Management system (PMS) is the procedure that clearly includes certification and support of the employees inside the organization and that decides the outcomes, across the norms that are set by the organization (Neelam, et al., 2013). The performance evaluation system can upgrade advantages through effective motivation and avoided the suspicions in the present system (Shahzadi, J, et al., 2014).

The motivational techniques marks the undergoing process, creates the main perspective in the organization workings that pay for performance has a motivational effect (Andersen \& Pedersen, 2012). Indeed, the researcher proposed that motivation is to enhance outward inspiration by managing a different professional's provisions indirectly through financial and nonfinancial rewards showing positive association among efforts inspiration and work satisfaction (Ubeda \& Santos, 2013).

Motivation is the main determinant of action in organization, and the moderating variable which inspire the employee performance (Bahrija, H \& Mirela, 2013). Research revealed that inspirational workings reflections at divergent and emergent situation and review of the belongings, dissatisfaction and in addition to achievement, the association between employment assignment and the appraisal to crave honed the fragment of basic mediators and the circumstance supporting, the generating costume of a self-reward strategy is the areas of motivation (Muhammad, 2014). In Pakistan, there are number of banks that utilize the performance management system (PMS) for improving their employee's performance.

\subsection{Problem Statement}

This research intends to investigate the performance appraisal system and its impact on employee performance including the moderating role of motivation among the employees. The study further identifies the issues of job performance through the moderating variable and calculates the impact of motivation on the performance among the employees' in the Banking sector especially in Dera Ismail Khan.

\section{Literature Review}

\subsection{Definition of Performance Appraisal}

Performance appraisal is a formal, structured system of measuring and evaluating an employee's job, related behaviors and outcomes to discover how and why the employee is presently performing on the job and how the employee can perform more effectively in the future so that the employee, organization and society are all benefited. (Verma, 2004: p. 100)

Every organization requires competent personnel to boost up their productivity. It is concerted effort of the human resource division / section to check the strength and weaknesses of their employees, the performance is connected to the actions and also incorporates judgment and appraisal process (Tett, Jackson \& Rothstein, 1995).The performance is not interrelated to the particular focus qualities but instead it contemplates the association among social and emotional environment (Bates \& Holton, 1995).

The existing literature revealed that performance evaluation has essential for bringing professional allied behavior (Babin \& Boles, 1996). The employees must trust that in Performance management (PM) there is examination system, improvements, rewards, inspirations and undesirable effect and dissatisfaction. Employees who got a high score on his/her examination are by and large inspired to perform well and look after his/her performance (DeNisi, et al., 1997).

Performance criteria spell out the particular components of an occupation and make it less demanding to add to the method for surveying levels of effective or ineffective employment performance (Sullivan \& Baghat, 1999). Generally it is observed in the organization that wrong things are appraised and the wrong techniques are utilized (Yousef, 2000).

\subsection{The Employees Motivation}

Motivation is the process that energizes employees and propels them to pursue their goals. Well-designed and wellexecuted performance appraisals have a strong motivational impact on the employees' performance. Appraisals have the power to motivate employees because they provide a number of interconnected benefits (Lloyd Kin, 2009). Various specialists exemplify motivation as the influence that invigorates, synchronizes, and supports conduct. The literature reveals that in the fastest growing markets, it is necessary to implement innovative human resource practices, motivation to gain market share (shaukat \& Surraya, 2013). Motivation is the inner urge inside of a man that direct individual to be goal focused (Hackman \& Oldham, 1997). Others believed a particular professional related connotation of motivation as the readiness to apply own caliber and molded efforts to achieve individual as well as organizational objectives (Gabris \& Simo, 1995). The requirement for work, motivation is an essential ingredient for enhancing employee performance. The literature revealed that the variables like; employees' learning, aptitudes, innovation, organizational atmosphere and management style, are imperative factors of the employees performance (Golshan \& Abraham, 1996). Research 
underlined that motivating factors can be attesting that the fit employees in the organization won't perform well except they are excited (Jurkiewicz, M, \& Brown, 1998). They also confirmed that the way to have a good job performance, human inspiration or employee's happiness is a more helpful for organizational survival (Deci, K \& Ryan, 1999, Humphrey et al., 2000). Persuaded employees are performing their task as characterized goals and they are committed.

Human asset is indispensable for any organization which breaks and makes the image of the organization. Motivated and happy workers are more productive than unhappy workers (Beach, 2008). The manager's tries to fulfill the workers demands in which performance appraisal is the best method with other means (Grote \& Grote, 2002). Employees of the organization work better when there is self-appraisal. They are inspired when their performance is assessed and remunerated suitably by any association. Performance appraisal is directly related with the employees and identifies issues with the occupation of the personnel. On the other hand there are no appraisals programs where they won't do that much work (Baumruk \& John, 2004). Performance appraisal is an essential fulfillment for employment in the organization and it is used a criterion for employee success.

\subsection{The Performance Appraisal and Motivation}

Performance Appraisal programs obviously assess and provide some assistance with setting target so as to define their destinations and future and finally to achieve the goal. Different researchers characterized that motivation as the eagerness to accomplish something, was molded by the action or the capacity to fulfill a few needs (Judge \& Ilies, 2002). Those enterprises understood that the activities of inspiring their employees are urgent and specific to accomplish the organizations goals (Schulze \& Steyn, 2003). The persuaded employees identify themselves with the conduct of and offer fulfillment and commitment that are relied upon to create better nature of work and oblige to the organizations' strategies which will broadly emerge efficiencies (Benabou \& Tirole, 2003). Motivation builds the occupation contribution by making the work more important and fascinating also it keeps the employees more gainful and enhances their work performance (Steers \& Shapiro, 2004).
The employee motivation is essential and most critical and the key characteristics of employees are checked eventually to achieve the organizational targets (Wang \& Guthrie, 2004). The scientists affirm that motivation to work plays very significant role in enhancing the output of the organization. It speaks to the intricate powers and needs which give the vitality for a person to perform a specific assignment (Mizuno, Yamada, Ishii \& Tanaka, 2006). In addition, employee motivation serves as a crucial part of professional operations whereby high motivation harmonizes with professional satisfaction, a sentiment of pride in individual work, a deep rooted obligation to organization which upgrades performance and efficiency (Davis, M \& Pandey, 2006). Similarly, for organizations, this component is valuable to look at the employees' performance. The literature revealed that there is equal relationship between the employees evaluating process, the employees' motivations and finally the employees' performance (Arbaiy \& Suradi, 2007).

The relevant literature highlights that performance appraisal studied staffing, training; rewarding and inspiration standards are four key strategies vital for guaranteeing the correct administration of an organization's human resources (Robbins \& Coulter, 2011). Besides, staffing, training and advancement depends on performance appraisal strategy establishment. In this way, the performance appraisal ought to go for contributing data on which these arrangements can be assembled. Performance appraisal arrangement can enhance representative performance and contribute towards workers (Simmons \& Lovegrove, 2013).

\subsection{List of Hypotheses}

Table 1. List of the Hypotheses

\begin{tabular}{|c|c|c|}
\hline Hypotheses & $\begin{array}{c}\text { Tools for } \\
\text { Analysis }\end{array}$ & Code \\
\hline $\begin{array}{c}\text { The predictor (performance appraisal) is } \\
\text { significantly positively correlated with the } \\
\text { Criterion (employees' performance) }\end{array}$ & Correlation & $\mathrm{H}_{1}$ \\
\hline $\begin{array}{c}\text { The predictors (performance appraisal \& } \\
\text { motivation) determine the Criterion } \\
\text { (employees' performance). }\end{array}$ & Regression & $\mathrm{H}_{2}$ \\
\hline $\begin{array}{c}\text { The Motivation brings a change as a } \\
\text { moderating variable between the } \\
\text { performance appraisal and the employee's } \\
\text { performance. }\end{array}$ & Regression & $\mathrm{H}_{3}$ \\
\hline
\end{tabular}




\subsection{Theoretical Framework}

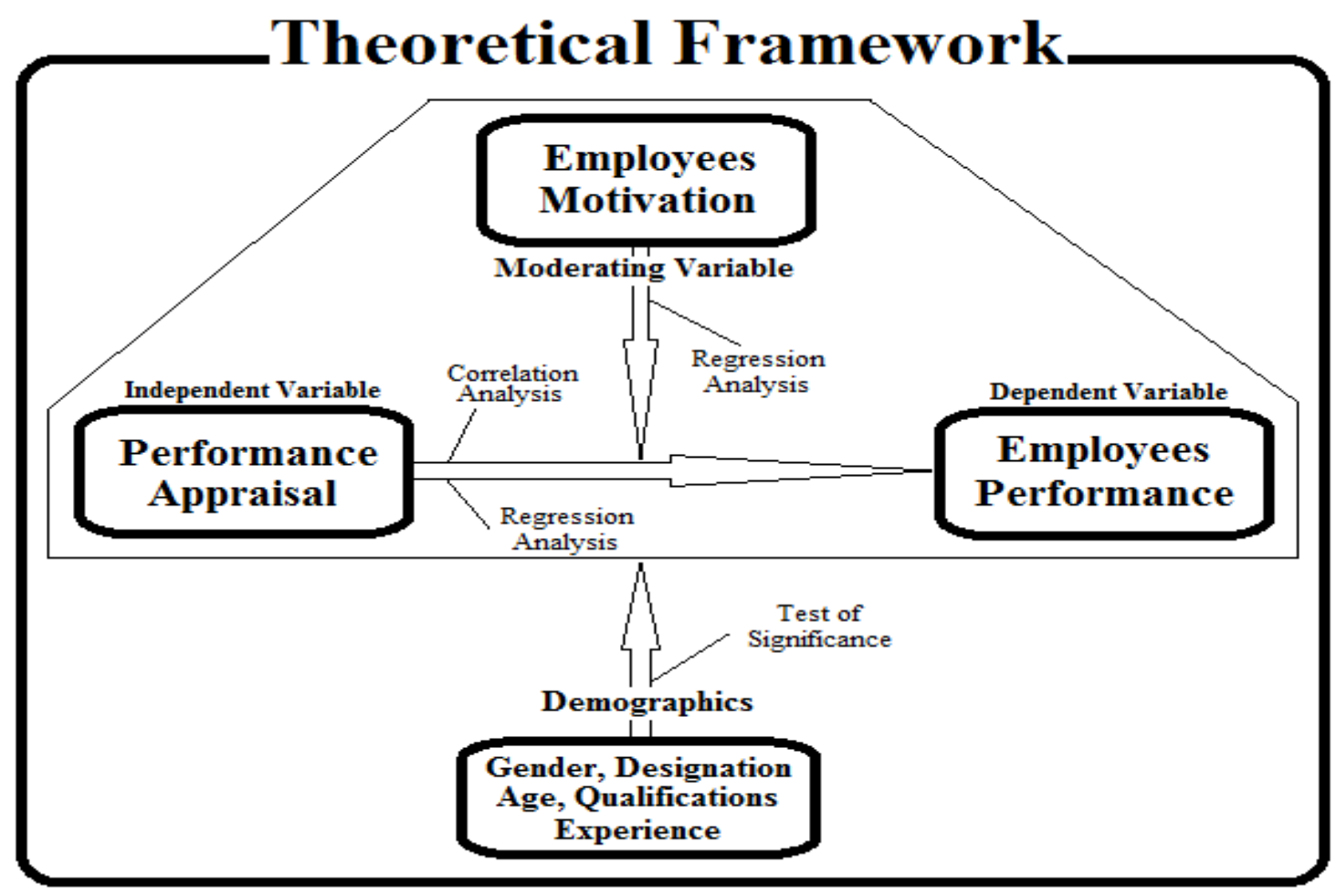

Figure 1. The Theoretical Framework

\section{Research Methodology}

\subsection{Survey Approach}

A survey is the best vehicle for measuring the attitude of the employees. "Social research methodology empowers the researcher to gather any kind of information thus studies are apparently the outstanding instrument for measuring methodology in enormous populations" (Sekaran, 1999).

\subsection{Population and Sample}

The population of the current study was the employees working in the banking sector i.e, MCB, UBL, HBL and Mizan Banks in Dera Ismail Khan, Khyber Pakhtunkhwa, Pakistan.).

Table 2. Sample Selection Process

\begin{tabular}{|c|c|c|}
\hline \multicolumn{2}{|c|}{ Statistics } & Value \\
\hline Standard Deviation & SD & 0.78 \\
\hline Population & $\mathrm{N}$ & 320 \\
\hline Error & $\mathrm{E}$ & 0.089 \\
\hline Level of Confidence & $\mathrm{Z}$ & 1.96 \\
\hline Sample & $\mathrm{n}$ & 150 \\
\hline
\end{tabular}

Sample-size $=\left(\left(\mathrm{SD}^{2} /\left(\left(\mathrm{Z}^{2} / \mathrm{E}^{2}\right)+\left(\mathrm{SD}^{2} / \mathrm{N}\right)\right)\right)\right.$

For selection of sample size by using the same formula from total population of (320), a sample of (150) was selected from the already mentioned banks of District Dera Ismail Khan. This population is the heterogeneous. Different age groups, difference in qualification level, designation and gender and experience as well..(see Table 3)

Table 3. Reliability Statistics

\begin{tabular}{|c|c|}
\hline \multicolumn{2}{|c|}{ Reliability Statistics } \\
\hline Category & Cronbach's Alpha \\
\hline Performance Appraisal & 0.795 \\
\hline Employees Motivation & 0.894 \\
\hline Employees Performance & 0.843 \\
\hline Overall & 0.806 \\
\hline
\end{tabular}

\section{Findings of the Study}

The researcher has tested only three hypotheses while the demographic impact must be checked in another paper. Due to time constraints and other formalities it compelled the researcher to explain following three research variables:

Hypothesis \# 1 Predictors are highly associated with Criterion variable

Hypothesis \# 2 The predictors (performance appraisal \& motivation) determine the Criterion (employees' performance).

Hypothesis\#3 Motivation which is moderating variable explains the impact on Criterion Variables. 
Table 4. Descriptive Statistics on research variables

\begin{tabular}{|c|c|c|c|c|c|}
\hline & $\mathrm{N}$ & Minimum & Maximum & Mean & Std. Deviation \\
\hline Performance Appraisal & 150 & 1.70 & 4.80 & 3.3993 & .63283 \\
\hline Employees Performance & 150 & 2.10 & 4.60 & 3.4440 & .55120 \\
\hline Employees Motivation & 150 & 1.90 & 7.70 & 3.5340 & .74165 \\
\hline Valid N (list-wise) & 150 & & & & \\
\hline
\end{tabular}

The above table 4 shows that the maximum average response of the respondents is (4.80) about the research variable Performance Appraisal and the lowest average response is (1.70). Further, the data analysis shows that that the maximum average response of the respondents about the Employees Performance remained (4.60) while the minimum average score for the same variable is (2.10). Similarly, the response rate for the Employees Motivation remained maximum (7.70) and the minimum rate is $(1.90)$ respectively.

\subsection{Testing of Hypotheses}

\subsubsection{Association of the Predictors and Criterion Variables}

Hypothesis \# 1 Predictors are highly associated with Criterion Variable

Table 5. Table of Correlations

\begin{tabular}{|c|c|c|c|c|}
\hline & & $\begin{array}{c}\text { Performance } \\
\text { Appraisal }\end{array}$ & $\begin{array}{l}\text { Employees } \\
\text { Motivation }\end{array}$ & $\begin{array}{l}\text { Employees } \\
\text { Performance }\end{array}$ \\
\hline \multirow{3}{*}{ Performance Appraisal } & Pearson Correlation & 1 & $.398^{* *}$ & $.645^{* *}$ \\
\hline & Sig. (2-tailed) & & .000 & .000 \\
\hline & $\mathrm{N}$ & 150 & 150 & 150 \\
\hline \multirow{3}{*}{ Employees Motivation } & Pearson Correlation & $.398^{* *}$ & 1 & $.437^{* *}$ \\
\hline & Sig. (2-tailed) & .000 & & .000 \\
\hline & $\mathrm{N}$ & 150 & 150 & 150 \\
\hline \multirow{3}{*}{ Employees Performance } & Pearson Correlation & $.645^{* *}$ & $.567^{* *}$ & 1 \\
\hline & Sig. (2-tailed) & .000 & .000 & \\
\hline & $\mathrm{N}$ & 150 & 150 & 150 \\
\hline
\end{tabular}

**. Correlation is significant at the 0.01 level (2-tailed).

The above table).(see Table 5)

indicates that all the research variables are significantly, positively associated with each other. However, the highest significant association with $\mathrm{r}=.645(.000)$ which is between performance appraisal and employees performance while the second largest association is between employees performance and employees motivation (.567) (.000). Similarly, the analysis shows the lowest association between the employees' motivation and the performance appraisal (.398) (.000). Thus on the basis of data analysis and all the evidences, our hypothesis that "all research variables are significantly and positively associated with each other", is accepted and substantiated

Hypothesis \# 2 The predictors (performance appraisal \& motivation) determine the Criterion (employees' performance).).(see Table 6)

Table 6. Regression: (without interaction effect)

\begin{tabular}{|c|c|c|c|}
\hline \multicolumn{3}{|c|}{ Variables Entered/Removed $^{\mathrm{b}}$} \\
\hline Model & Variables Entered & Variables Removed & Method \\
\hline 1 & Employees Motivation, Performance Appraisal & Enter \\
\hline a. All requested variables entered. & \\
\hline b. Dependent Variable: Employees Performance & \\
\hline
\end{tabular}


Impact of Performance Appraisal on Employee's Performance Including the Moderating Role of Motivation: A Survey of Commercial Banks in Dera Ismail Khan, Khyber Pakhtunkhwa, Pakistan

Table 7. Model Summary

\begin{tabular}{|c|c|c|c|c|}
\hline Model & $\mathrm{R}$ & R Square & Adjusted R Square & Std. Error of the Estimate \\
\hline 1 & $.728^{\mathrm{a}}$ & .530 & .523 & .38049 \\
\hline \multicolumn{5}{|c|}{ a. Predictors: (Constant), Employees Motivation, Performance Appraisal } \\
\hline
\end{tabular}

Table 8. Coefficients

\begin{tabular}{|c|c|c|c|c|c|c|}
\hline & \multirow{2}{*}{ Model } & \multicolumn{2}{|c|}{ Unstandardized Coefficients } & \multirow{2}{*}{$\frac{\text { Standardized Coefficients }}{\text { Beta }}$} & \multirow{2}{*}{$\mathrm{t}$} & \multirow{2}{*}{ Sig. } \\
\hline & & B & Std. Error & & & \\
\hline \multirow{3}{*}{1} & (Constant) & 1.002 & .192 & & 5.210 & .000 \\
\hline & Performance Appraisal & .434 & .054 & .498 & 8.076 & .000 \\
\hline & Employees Motivation & .274 & .046 & .369 & 5.979 & .000 \\
\hline
\end{tabular}

\section{(see Table 1)}

This table shows the individual contribution of the independent variable e.g; performance Appraisal and Employee motivation can be seen in the table of coefficient of regression via Beta value in the table, the weights of each independent variable is visible in the column titling standardized coefficient the Beta value for performance appraisal is 0.498 while it is 0.369 for the variable of employee Motivation.

Hypothesis\#3 Motivation which is moderating variable explains the impact on Criterion Variables.

Table 9. Regression: (with interaction effect)

\begin{tabular}{|c|c|c|c|}
\hline \multicolumn{4}{|c|}{ Variables Entered/Removed ${ }^{\mathrm{b}}$} \\
\hline Model & Variables Entered & Variables Removed & Method \\
\hline 1 & Employees Motivation, Performance Appraisal & . & Enter \\
\hline 2 & interaction $^{\mathrm{a}}$ & . & Enter \\
\hline \multicolumn{3}{|c|}{ a. All requested variables entered. } & \\
\hline
\end{tabular}

Table 10. Model Summary

\begin{tabular}{|c|c|c|c|c|c|c|c|c|c|}
\hline \multirow{2}{*}{ Model } & \multirow{2}{*}{$\mathrm{R}$} & \multirow{2}{*}{ R Square } & \multirow{2}{*}{ Adjusted R Square } & \multirow{2}{*}{ Std. Error of the Estimate } & \multicolumn{5}{|c|}{ Change Statistics } \\
\hline & & & & & R Square Change & F Change & df1 & df2 & Sig. F Change \\
\hline 1 & $.728^{\mathrm{a}}$ & .530 & .523 & .38049 & .530 & 82.844 & 2 & 147 & .000 \\
\hline 2 & $.732^{\mathrm{b}}$ & .536 & .526 & .37930 & .006 & 1.924 & 1 & 146 & .168 \\
\hline \multicolumn{10}{|c|}{ a. Predictors: (Constant), Employees Motivation, Performance Appraisal } \\
\hline \multicolumn{10}{|c|}{ b. Predictors: (Constant), Employees Motivation, Performance Appraisal, interaction } \\
\hline
\end{tabular}

Table 11. Coefficients

\begin{tabular}{|c|c|c|c|c|c|c|}
\hline & \multirow{2}{*}{ Model } & \multicolumn{2}{|c|}{ Unstandardized Coefficients } & \multirow{2}{*}{$\frac{\text { Standardized Coefficients }}{\text { Beta }}$} & \multirow{2}{*}{$\mathrm{t}$} & \multirow{2}{*}{ Sig. } \\
\hline & & B & Std. Error & & & \\
\hline \multirow{3}{*}{1} & (Constant) & 1.002 & .192 & & 5.210 & .000 \\
\hline & Performance Appraisal & .434 & .054 & .498 & 8.076 & .000 \\
\hline & Employees Motivation & 274 & .046 & .369 & 5.979 & .000 \\
\hline \multirow{4}{*}{2} & (Constant) & .037 & .722 & & .051 & .960 \\
\hline & Performance Appraisal & .722 & .215 & .829 & 3.363 & .001 \\
\hline & Employees Motivation & .577 & .223 & .776 & 2.586 & .011 \\
\hline & interaction & -.089 & .064 & -.624 & -1.387 & 168 \\
\hline
\end{tabular}


From the results given in table we can observe that although Model 2 with the interaction between performance appraisal and employees motivation accounted for more variance than just performance appraisal and employees motivation level by themselves, $\mathrm{R}^{2}$ change $=.006$ however it is insignificant with $p=.168$, indicating that there is no moderation effects of employees motivation on the relationship between performance appraisal and employees performance and hypothesis \# 3 of the study is not substantiated.

\section{Discussions}

With the changeable business environment and serious business rivalry, the Banks are required to achieve predetermined target. This performance identifies with the foundation or individual level which sees the human motivation turning into the most deciding component to accomplish the institutional business operations (Rizwan \&Fawad, 2010). Organizational performance is an indication of an establishment to effectively accomplish goal. For that purpose the employees' performance is essential for enhancing banks profitability. A few researchers inquires have been acquainting different systems with assess employees' performance (Hayat \&Riaz, 2011). This incorporates the quality, amount, learning or imagination of individual towards the proficient works feasible through better appraisal system. There are some standard parameters that can depend upon employee performance (Ikramullah et. al, 2011). It varies from individual to individual as well as distinctive purposes of time within the organization.

The main goal of the study was to determine the vision of the bank authorities' the impact of performance examination system on performance and motivation of the bank authorities. The result of the study showed that the respondents viewed employees performance are increased through financial emoluments Such evaluation of employee performance generates the motivation and ensure efficiency.

Moreover, the evaluation system emphatically impacts the scholastics' motivation and performance. The outcomes mean a solid relationship between performance evaluation and the employee's performance and motivation. By this outcome, the dire need to survey the present performance evaluation system, measures and compensates impacts employee performance,

The study focuses on the association between performance evaluation and employee's performance and remunerating thought to the motivation as a moderator. The results demonstrate that there is critical association between performance evaluation and performance of employees. The inspiration makes it more solid and explained the relationship between performance evaluation and worker performance of employees in the banks of Dera Ismail Khan, likewise bolstered by the past investigations (Peti\& Johann,
2001; Lillian \& Mathooko, 2011; and Fakharyan \& Dehafarin, 2012), have been confirmed the relationship between performance appraisal and employees' performance.

\section{REFERENCES}

[1] Ahmad..R, \& Ali, N.A. (2004). Performance appraisal decision in Malaysian public service. International Journal of Public Sector Management, 17(1), 48-64.

[2] Ahmad. R, \& Bujang. S, (2013) Issues and challenging in the practice of performance activities in the $21^{\text {st }}$ century. International Journal of education and research Vol. 1 (4) 2013.

[3] Andersen, L. B., \& Pedersen, L. H. (2012). Public Service Motivation and Professionalism. International Journal of Public Administration, 35 (1): 46-57.

[4] Arbaiy, N., \& Suradi, Z. (2007). Staff performance appraisal using fuzzy evaluation. International Federation for Information Processing, 247: 195-203.

[5] Armstrong, M., \& Baron, A. (2005). Managing performance: Performance management in action. New York, Mc Graw Hill Book Co.

[6] Babin, B. J., \& Boles, J. S. (1996), "The effects of perceived co-worker involvement and supervisor support on service provider role stress, performance and job satisfaction", Journal of Retailing, 72, 57-75.

[7] Bahrija Umihanic, B., Herzegovina, \& Mirela Cebic (2013). "Functions of the Performance Appraisal System: Analyses and their Impact on Level of Employees' Motivation." International Journal of Sustainable Economies Management, 1(1): 1-15.

[8] Bates, R.A. \& Holton, E.F. (1995). Computerized Performance Monitoring: A Review of Human Resource Issues. Human Resource Management Review, Winter, 267288 .

[9] Becker, K., Antuar, N., \& Everett, C. (2011). Implementing an Employee Performance Management System in a Nonprofit Organization. Nonprofit Management and Leadership. 21 (3), 255-271.

[10] Benabou, R., \& J. Tirole (2003). "Intrinsic and Extrinsic Motivation", Review of Economic Studies 70, 489-520.

[11] Boswell, W. R., \& Boudreau, J. W. (2002). Separating the Developmental and Evaluative Performance Appraisal Uses. Journal of Business and Psychology 16 (3): 391-412.

[12] Buelens, M., \& Broeck, H. V. (2000). An Analysis of Differences in Work Motivation Between Public and Private Sector Organizations. Public Administration Review, 67 (1): 65-74.

[13] Burney, L., \& Widener, S. K. (2008). 'Strategic performance measurement systems, job- relevant information and managerial behavioral responses-Role and Performance Behavioral', Research in Accounting, 19, 43-69. 
[14] Christensen, R. K., \& Wright, B. E. (2010). The Effects of Public Service Motivation on Job Choice Decisions: Disentangling the Contributions of Person-Organization Fit and Person-Job Fit'. Journal of Public Administration Research and Theory 21 (4): 723-743.

[15] Davis, L., Marlowe, J., \& Pandey, S. K. (2000). Gender Dimensions of Public Service Motivation. Public Administration Review, 66 (6): 871-85.

[16] Deci, E. L., Koestner, R., \& Ryan, R. M. (1999). A metaanalytic review of experiments examining the effects of extrinsic rewards on intrinsic motivation. Psychological Bulletin, 125(6): 627-668.

[17] De- Nisi, A. S., Robbins, T. L., \& summers, T. P. (1997). Organization, processing, and Use of Performance Information: a Cognitive Role for Appraisal Instruments," Journal of Applied Social Psychology, 27: 1884-1905.

[18] Diefendorff, J. M., \&Chandler, M. M. (2011). Motivating Employees, in S. Zedeck (ed), APA Handbook of Industrial and Organizational Psychology, Volume 3, Washington D.C., American Psychological Association.

[19] Donnell, M., \& Shields, J. (2002). "Performance management and the psychological contract in the Australian federal public sector", Journal of Industrial Relations, Vol. 44 No.3, pp.435-57.

[20] Erdogan, B., Kraimer, M. L. \&Liden, R. C. (2001). Procedural justice as a two-dimensional construct: An examination in the performance appraisal context. Journal of Applied Behavioral Science, 37(2), 205-222.

[21] Filipkowski, M., \& Johnson, C. M. (2008). Comparisons of Performance and Job Insecurity in Union and Non-union Sites of a Manufacturing Company. Journal of Organizational Behavior Management, 28 (4), 218-237.

[22] Gabris, G. T., \& Simo, G. (1995). Public Sector Motivation as an Independent Variable Affecting Career Decisions. Public Personnel Management 24 (1): 33-49.

[23] Giangreco. A, Carugati A., Sebastiabo A., Al Tamimi H., (2012) War outside, ceasefire Inside: An anaylsis of the performance Appraisals system of a public hospital in a zone of conflict, Evaluation and Program planning, 35 (1) Pp. 161-170.

[24] Golshan \& Abraham. (1996). Theory of perception and its role in personal motivation. Management in education, 2 (4): $22-2$.

[25] Grund, C., \& Dirk, S. (2009). The Anatomy of Performance Appraisals in Germany. The International Journal of Human Resource Management 20(10): 2049-65.

[26] Gure, D., \& Naima, A. (2009). The Impact of Motivation on Employee Performance: A Study of Nation link Telecom Somalia, Master's thesis, University Utara Malaysia.

[27] Hackman, J. R., \& Oldham, G. R. (1997). Motivation through the Design of Work: Test of a Theory. Organizational Behavior and Human Performance, 16: 250-279.

[28] Hayat, N., \&Riaz, M.T. (2011). The entrepreneurial orientation can enhance the teacher performance in higher education. Revista Romaneasca Pentru Educatie Multi dimensionala, 3(8), 85-96.
[29] Humphrey, S. E., \& Nahrgang, D., \&Morgeson, P. (2007). Integrating Motivational, Social, and Contextual Work Design Features: A Meta-Analytic Summary and Theoretical Extension of the Work Design Literature. Journal of Applied Psychology, 76(2), 186-198.

[30] Ikramullah, M, I. U., Bahadar, S.,Zaman, T., \& Hamad, K. (2011). Fairness Perceptions of Performance Appraisal System: An Empirical Study of Civil Servants in District Dera Ismail Khan, Pakistan. International Journal of Business and Social Science, 2 (21), 92-100.

[31] Iskandar, M., Ahmad, R., \& Martua, R. H. (2013). Factors Influencing Employees' Performance: A Study on the Islamic Banks in Indonesia. International Journal of Business and Social Science, 5 (2).

[32] Jan, S., Israr, M., Haq, Z., Tariq, M., \& Jahangir, M. (2014). "The effect of performance Management system on teacher's efficiency: A case study of private schools in district Peshawar". Life Science Journal; 11(4):79-85.

[33] Jaramillo, F., Mulki, J. P., \& Marshall, G. W. (2004). A metaanalysis of the relationship between organizational commitment \& salesperson job performance: 25 years of research. Journal of Business Research, 58, 705-714.

[34] Judge, T. A., \& Ilies, R. (2002). Relationship of personality to performance motivation: A meta-analytic review. Journal of Applied Psychology, 87(4):797-807.

[35] Judge, T. A., \&Ilies, R. (2002). Relationship of personality to performance motivation: A meta-analytic review. Journal of Applied Psychology, 87(4):797-807.

[36] Jurkiewicz, C., Massey, T., \& Brown, R. (1998). Motivation in Public and Private Organizations: A Comparative Study. Public Productivity \& Management Review, 21 (3): 230-250.

[37] LLoyed Ken (2009) Performance Appraisals' and Phrases. For Dummies. A Wiley Brand USA.

[38] Meysam Fakharyan, M. R. J., Behrooz Dini, Ebrahim Dehafarin (2012). "The Effect of Performance Appraisal Satisfaction on Employee's Outputs Implying on the Moderating Role of Motivation in Workplace." International Journal of Business and Management Tomorrow, 2(4): 2249-9962.

[39] Mizuno, M., Yamada, Y., Ishii, A., \& Tanaka, S. (2006). A human resource management approach to motivation and job stress in paramedics. International Congress Series, 1294, 167-170.

[40] Mohammad, H. K., Mehrzad, H., Mahmoud, G., \& Mohammad, H. (2012). Identification of Organizational Factors Associated with IOC Employees Performance Based on Wise Board Model. International Journal of Academic Research in Business and Social Sciences, 2 (6), 396-204.

[41] Moynihan, D. P., \& Pandey, S. K. (2001). The Role of Organizations in Fostering Public Service Motivation. Public Administration Review, 67 (4): 40-53.

[42] Muhammad, F. U. (2014).Role of Performance Appraisal System on Employees Motivation. Journal of Business and Management, 8 (4), 66-83.

[43] Neelam, T., Israr, K. Y., Shahid, J., \&Hashim, M. (2013). The Impact of Training and Development on Employees Performance and Productivity: A case study of United Bank 
Limited Peshawar City, KPK, Pakistan. International Journal of Academic Research in Business and Social Sciences, 4 (4), 86-98.

[44] Perry, J. L., \& Hondeghem, A. (2008). Motivation in Public Management. The Call of Public Service. New York: Oxford University Press.

[45] Rizwan, M., \& Fawad, S. (2010). Relationship of Job Involvement with Employee Performance: Moderating Role of Attitude, European Journal of Business and Management, $3(8), 77-85$.

[46] Shahzadi, I., Javed, A., Pirzada, S. S., Nasreen, S., \& Farida, K. (2014). Impact of Employee Motivation on Employee Performance. European Journal of Business and Management, 6 (23), 159-176.

[47] Shaukat, M.M. \& Surrayya Aslam (2013) Performance Appraisal and Employee Motivation. A comparative analysis of Telecom Industry in Pakistan. Pakistan Journal of social Sciences (PJSS) Vol. 33, No.1 Pp. 179-189.

[48] Shields \& John. (2007). Managing employee performance and reward: concepts, practices, strategies. Cambridge, New York: Cambridge University Press.

[49] Steers, R. M., \& Shapiro, D. L. (2004). The Future of Work Motivation Theory. Academy of Management Review, 29 (3): 379-387.
[50] Sullivan, S. E., \& Baghat, R. S. (1999). Organizational stress, job satisfaction, and job performance: Where do we go from here? Journal of Management, 18, 353-375.

[51] Taylor, M. S., Tracy, K. B., Renard, M. K., Harrison, J. K., \& Carroll, S. J. (1995). Due process in performance appraisal: A quasi-experiment in procedural justice. Administrative Science Quarterly, 40(3), 495-523.

[52] Ubeda, C. L., \& Santos, F. C. (2013). Staff development and performance appraisal in a Brazilian research Centre, European Journal of Innovation Management, 10(1): 109125.

[53] Verma, A.P (2004). Human Resource Management S. K. Kataria \& Sons, Publishers and Distributors 6. GURU NANAK MARKET, NAI SARAK, DELHI-110006.

[54] Wang, J. H., \& Guthrie, J. T. (2004). Modeling the effects of intrinsic motivation, extrinsic motivation, amount of reading achievement on text comprehension between US and Chinese students, Reading Research Quarterly. 39(4), 16286.

[55] Yousef, D. A. (2000). Organizational commitment: a mediator of the relationships of leadership behavior with job satisfaction and performance in a non-western country. Journal of Managerial Psychology, 15(1): 6-24. 